\title{
Sammenhængskraft, bæredygtighed, meningsfuldhed, værdibevidsthed og ytringsfrihed er blevet nogle af de vigtige elementer i samfundsdebatten. Men er de i stand til at skabe et bedre og mere demokratisk og retfærdigt menneskesamfund?
}

\author{
Af Preben Melander *)
}

Det vrimler i disse krisetider med nye ideer og perspektiver på fremtidens samfundsudvikling. Nye bøger og artikler om det gode lederskab anviser nye opskrifter på lederskabelse. Politikerne snakker om flotte reformer og teknologier, der skal bringe planeten og vores natur i en bedre økologisk balance. De store ambitiøse verdensmål er blevet formelt vedtaget. Men de forbliver at være smukke symboler, der først skal realiseres over mange år. Disse programmer italesættes ofte af etablerede ledere, der sidder i sikre positioner, ofte langt fra problemerne og realiteterne. En forandring kræver i stedet et bredt demokratisk engagement og et samarbejde, som vil alle skal stå bag. Men det er ofte svært at etablere i praksis, hvis alle skal være enige og bidrage.

Problemet er, at skabelsen af et bæredygtigt, demokratisk og retfærdigt menneskesamfund forudsætter, at både politikerne og ikke mindst borgerne forstår, hvad et demokrati indebærer. Vi må sætte os ind i, hvordan vi som mennesker kan leve op til demokratiets krav og normer. Og vi må stille klare krav til vore politikere, når de skal leve op til demokratiets grundliggende værdier. Derfor må vi have tillid til politikernes samfundsansvarlighed, åbenhed og troværdighed. Det kan være svært, hvis politikerne tror, at de er deltagere i et medie- og realityshow. Det kræver også, at vi som borgere har en viden, bevidsthed og en samfundsmæssig dannelse, som sætter os i stand til at deltage at i den politiske samtale.

Det er desværre ikke altid noget, som vi som borgere har lært. Det gælder hverken i skolen, på

*) Preben Melander professor emeritus og ansvarshavende for SiS 
uddannelserne, ude i arbejdslivet etc. Således savner vi overalt en social og kritisk debat om, hvad demokrati er, og hvad det kræver af social adfærd på tværs. Ellers lykkes det ikke at ændre verden. Når der så i samfundet generelt eksisterer en folkelig mistillid til politikerne, kan et demokrati af gode grunde ikke fungere, hverken på de efterfølgende niveauer eller på tværs af samfundet.

Set over de sidste 30 år er den demokratiske samfundsbevidsthed og politiske samtale såvel ude i vore organisationer, mellem vores samfundsinstitutioner som på tværs af verdens lande set over en bred kam blevet forringet. Verdenssamfundet er i dag præget af stadig flere konflikter og mindre respekt for demokratiet og menneskerettighederne. Stormagterne USA og Kina kæmper om verdensherredømmet, hvilket resulterer af en forøgelse af samfundets centralisme og nedtoning af menneskers frihedsrettigheder. Derudover ser vi stadig flere stater som f.eks. Iran, Nordkorea, Tyrkiet og Rusland bidrage til den globale politiske usikkerhed gennem deres farlige konfrontatoriske spil, styret af egne indenrigs problemer. I de sidste 15 år ser vi samtidigt klare tendenser til, at det internationale samarbejde er præget af opløsning og kriser. De Forenede Nationer (FN) har ikke mere den samme politiske indflydelse som tidligere. Andre internationale samarbejdsorganisationer som EU og NATO har mistet sammenhængskraften. Mange nationer foretrækker at stå alene og bevidst modarbejde fællesskabet. Demokratier erstattes stadig flere steder af autokratier, som underminerer demokratiet indefra. Den hastige teknologiske, økonomiske og videnmæssige udvikling har øget den globale konkurrence og forstærket de politiske og sociale spændinger og sig-selv-nok manifeststationer. Også set i det lys står demokratiet som taber.

Det bedste, vi kan gøre som et lille samfund i et splittet globalt univers, er at prøve overalt at skabe dialog og samarbejde. Dette gælder såvel mellem lande, organisationer, institutioner som grupper, som arbejder for at styrke demokratiet. Derfor er et øget samarbejde på tværs af de skandinaviske lande en vigtig udviklingsopgave. Dette gælder ikke mindst indenfor samfundsforskningen, som SIS er en del af. Ved at skabe og markere et demokratisk synligt forbillede kan vi håbe på, at den demokratiske model kan få større styrke og udbredelse. Men det er vigtigt, at denne samfundsskabende idé demonstreres og styrkes på alle måder og på alle niveauer i samfunds- og lederskabelsens navn.

Lad os til sidst nævne nogle lokale eksempler på vidennetværk, hvor vi som forskere har haft som mål at styrke leder- og samfundsskabelsen.

På CBS etablerede vi i 2012-14 et videnudviklingsprogram på tværs af en række af vores store private og offentlige organisationer. Formålet hermed var at styrke det faglige og ledelsesmæssige samarbejde. I alt 14 danske topledere blev inviteret til at fremlægge og forsvare deres ledelsesideer for en åben kreds. De blev samtidigt udnævnt til adjungerede professorer og inviteret til en række 
formidlingsaktiviteter. Samarbejdet resulterede i en række tværgående ledelsesideer og involverede en breds kreds af interessenter.

Et andet tværgående samarbejdsprogram blev etableret i 1984 på tværs af de nordiske lande omkring fagtidsskriftet Økonomistyring \& Informatik. Tidsskriftet ændrede navn i 2014 til Samfundslederskab i Skandinavien (SIS) med deltagelse af såvel forskere som ledere i Norge, Sverige og Danmark. Formålet var her at styrke det nordiske samarbejde omkring ledelse og lederskabelse indenfor det skandinaviske sprogområde. Tidsskriftet er digitalt og gratis og læses af ca. 5.000 mennesker i Skandinavien.

Svaret på denne artikels overskrift er, at et frivilligt samarbejde mellem frie ildsjæle kan bringes til at fungere og styrke samfundsudviklingen på tværs, hvis de etablerede sociale netværk får lov til at folde sig ud med afsæt i deres iboende mission. 